\title{
The Effect of Green Practices on Tourists' Behavioral Intention: A Study of Hoteliers in Central Province of Sri Lanka
}

\author{
R.S.S.W. Arachchi \\ Department of Tourism Management, Faculty of Management Studies, \\ Sabaragamuwa University of Sri Lanka. \\ ranganashalika1980@gmail.com
}

Received: August 08, 2019

Accepted: October 22, 2019

\section{ABSTRACT}

The tourism industry has experienced a rapid growth in the recent past. Many alternative forms of eco-tourism have become one of the most attractive niche forms as it causes less harm to the natural environment. As Sri Lanka is rich with natural and social varieties, it can build up the ecotourism concept for the advantage of the Sri Lankan economy. The researcher became interested in eco concepts and conducted the study in order to identify the effect of green practices on tourists' behavioral intentions. The findings of the study show that green practices of the hoteliers strongly affect the behavioral intention of the tourists. Based on the managerial implication of these findings, hoteliers should pay more attention to the effect created by the green practices on tourists. The findings of this study can be applied to improve the eco-tourism concept in Sri Lanka.

Keywords: Eco-tourism, Green practices, Tourists' satisfaction, Tourists' behavioral intention

\section{Introduction}

\subsection{Background of the Study}

Over the past few years, tourism experienced continuous diversification and became one of the fastest-growing sectors in the world (World Tourism Organization, n.d). Tourism generates large amounts of income to the 
economy, accounting for $30 \%$ of the world's trade of services. With the popularity of niche forms of tourism, eco-tourism has turned out to be one of the most demanded forms among vacationers around the globe. Since Sri Lanka is rich with many social and natural varieties, it can build up the ecotourism concept for the advantage of the Sri Lankan economy and community much better than the other countries (SLEF, cited in Arachchi, Yajid, \& Khatibi, 2015). Compared to the past, at present, tourists are more knowledgeable, and they are highly concerned about the negative impacts generated through their activities, especially on the environment. According to Lee, Hsu, Han \& Kim (2010) green hotels' overall image, in turn, can contribute to more favorable behavioral intentions. With the changes in the mindsets of the tourists towards the environment, most hoteliers currently pay more attention to sustainable management operations (Lee \& Moscardo, 2005).

Even though tourists do their best to protect the environment, sometimes hoteliers cheat them by promoting their hotels as eco-friendly hotels. So, tourists become victims of "greenwashing." Greenwashing is a practice that misleads customers about the environmental benefits of a product, services, or company practices. A hotel may appear more eco-friendly than it is. There are many hotels in the Central Province of Sri Lanka that promote themselves as "green" through websites. This study attempts to explore the existing green practices of hoteliers in the Central Province and their effect on the behavioral intentions of tourists.

\subsection{Problem Statement}

The awareness and the preferences of staying in the green accommodation of global travelers are increasing rapidly. According to the report by bookings.com, the number of travelers who are staying in eco-friendly or 'green' accommodation at least once could be doubled in the next year with an increase of $65 \%$ of global travelers. Apart from that, $68 \%$ confirm that they are more likely to choose an accommodation knowing that it was ecofriendly, with Chinese (93\%), Brazilian (83\%) and Spanish (80\%) travelers 
(Booking.com Reveals 2017 Sustainable Travel Intentions, Goals and Considerations, 2017).

In many cases, tourists rely on hotels' marketing activities, their services, environmental information, etc. because it is difficult for them to assess when selecting a hotel. Some hoteliers consider themselves green, but no green practices can be found out and create only some unsatisfied customers. Dissatisfied customers would never recommend the hotel for anyone, and also greenwashing affects the behavioral intentions of the tourists (Cary, Bhaskaran, \& Polonsky 2004). Misleading green marketing damages not only themselves but also creates damages to the hotels that are practicing the green concept. The researcher has done a web survey based on the Trip Advisor comments of the eco-resorts to identify the customer comments on eco practices of hotels in Sri Lanka and found that, "eco" has just become a buzzword and it has been misused by the hoteliers in Sri Lanka to promote their accommodations.

Some research studies related to eco-tourism in Sri Lanka have been carried out, but recently, we hardly found research articles related to the green practices of hoteliers and tourist behavioral intentions. With time some changes may occur in the tourist preferences and also in the green practices of hoteliers in Sri Lanka. Hence, the present study attempts to explore the green practices of hoteliers in Central Province and its effects on tourist behavioral intentions.

\subsection{Research Questions}

- How do eco practices of hoteliers affect the behavioral intentions of tourists?

- How do eco practices of hoteliers affect the satisfaction of tourists? 


\subsection{Research Objectives}

- To identify the effect of eco practices on tourists' behavioral intentions.

- To identify the effect of eco practices of hoteliers for tourists' satisfaction levels.

\subsection{Significance of the Study}

Ecotourism is becoming popular all around the world. Sri Lanka, as a county rich in biodiversity, has significant potential in this area. Despite the high volume of researches on eco-tourism in recent years, a limited effort has been directed towards eco practices among hoteliers in developing countries. The research provides some information for the tourists on eco practices of Sri Lankan hoteliers, the areas they should pay more attention to while selecting green accommodation. This study is expected to shed light on the concept of greenwashing with specific attention to the practice of hoteliers in Sri Lanka. It also provides support for the government policymakers to influence green practices by creating rules and regulations to reduce the negative impacts of tourism.

This would help the hoteliers to identify their current situation on eco practices and up to which extent they have to uplift their practices to increase the tourist satisfaction and behavioral intentions. So this study will help to improve the current condition of the tourism industry in Sri Lanka and to conserve the environment for the future.

\subsection{Scope of the Study}

Among many alternative forms of tourism, ecotourism has become a huge trend in current society. Although the eco concept is practiced by different stakeholders of tourism, this study only focuses on the accommodation sector. The researcher has selected Central province as the geographic area. 
According to the SLTDA accommodation guide a majority of the selfdeclared eco-resorts were found in the Kandy area. Therefore, Kandy was selected as the area of study. Hotels that were selected for the study are registered under the Sri Lankan Tourism Development Authority, and also they promote their green practices through their web sites.

\section{Literature review}

\subsection{Ecotourism}

The term "eco-tourism" has created a huge interest among people all around the world and has become increasingly popular in recent years, especially in the market place (Bottrill \& Pearce, 1995). As eco-tourism has developed, its effects have become more evident, and some instances have been indistinct from mass tourism, and definitions have turned out to be more elaborate (Campbell, 1999). It is thought to be more complex than "tourism to natural areas," and it includes the aspects of resource conservation and community development (Ross \& Wall, 1999). However, many definitions argue that ecotourism should attempt to do more than simply minimizing the impacts. Eco-tourists should also contribute to the health and good quality of the natural attractions that they visit. It may be one of the challenges of the ecotourism industry when it is moving the ecotourists from a minimal 'passive' position to a more 'active' contribution to the sustainability of 'eco-attractions' (Orams, 1995). Environmental concerns about tourism impacts have increased, and the tourist accommodation sector has identified the necessity to improve its sustainable management and process (Trauer, 1998). The development of eco-tourism resorts is one example of this change of more sustainable tourist accommodations.

An eco-resort is an establishment that provides hospitality services to ecotourists while performing eco-tourism principles. All eco-resorts imitate the inventive plans and entrepreneurialism of business founders, rather than the large multinational companies. Eco resorts often contribute towards 
maintaining officially protected areas, because they are frequently reliant on the appropriate management of government-controlled reserves. These eco-resorts may enthusiastically contribute to trail the maintenance, volunteer research programs, clean-up days, or the checking of visitor usage, depending on the local condition (The International Ecotourism Society, 1993). Providing ecotourism means making the resources that people need to get involved in ecotourism activities available. Eco-tourism is typically provided by a link of businesses that, together, offer different products and services needed by the eco-tourists. This includes food services and food supplies, sports and outfitting equipment and supplies, lodging, and guide services. The main issue of the eco-tourism concept is the misuse or misunderstanding of it, which does not explain the original meaning (Garrod \& Fyall, 1998). This is frequently attributed to the vagueness of its definitions. With several meanings and redefinitions over the years, it is tough to control it (Font, 2002). It is not only tourism developers who become the culprits of redefining the concepts to match their own ideas, authors of journals and books on the subjects while continuously mixing new definitions, each of which is fairly different, focusing on one or more of its features. When eco-tourism is rising with a good reputation, sometimes similar to traditional mass tourism, its definitions have been extended to mix ideas about eco-tourist responsibility; environmentally friendly destination management, profit connections to conservation efforts, and sustainable development of local human populations (Campbell, 1999). The main issue of the eco-tourism concept is the misuse or misunderstanding of it which does not explain the original meaning (Garrod \& Fyall, 1998). This is frequently attributed to the vagueness of its definitions. With several meanings and redefinitions over the years, it is tough to control it (Font, 2002). It is not only tourism developers who become the culprit of redefining the concepts to match their ideas, but authors of journals and books on the subject are also continuously mixing new definitions each of which is fairly different, focusing on one or more of its features. When eco-tourism is rising with a good reputation, sometimes similar to traditional mass tourism, its definitions have been extended to mix ideas about eco-tourist 
responsibility; environmentally friendly destination management, profit connections to conservation efforts, and sustainable development of local human populations (Campbell, 1999).

\subsection{Green Hospitality Industry and Eco Practices}

The green hospitality industry began in the middle of the 1990s with a few numbers of individuals and chain affiliated resorts and hotels (Melissen \& Roevens, 2007). The fundamental area of green approaches was to reduce water, energy and waste consumption (Nair \& Ananthrajah, 2012). Green practices in a lodging industry context refer to "concerted and deliberate efforts and practices by lodging operations and their agents to mitigate, ameliorate and eliminate the negative impacts of lodging activities on the environment." Initiatives in energy and water conservation, waste reduction, recycle and reuse initiatives, building infrastructure and environmental education and awareness, credible certification programs such as Green Seal, Leadership in Energy and Environmental Design (LEED), Green Leaf, Green Key, The Green Tourism Business Scheme (GTBS) are increasingly being used by hoteliers ( Jackson , 2010). Also, Ayala's (1995) study also shows a strong partnership between eco-tourism and the resort industry (Jamaluddin, 2004). An eco-tourism firm can be recognized as a monopolistic competitor giving eco-tourism practices as a marketing strategy to set it eliminating the competition. Mainly, this firm should obtain positive economic profits. These large profits will improve the incentive to preserve the resources and to reduce the destructive externalities related to tourism. Finally, other sites, observing the accomplishment of the present firm, will come into the market, offering similar tours (Isaacs, 2000). Further, he stated that some customers would be drawn to competing sites. As a result of declining returns, a rational business person may attempt to increase profits by reducing financial costs or growing demand. Either one of these efforts can negotiate the firm's loyalty for eco-tourism principles. The eco-resort operator may try to cut expenses by dropping efforts to control the external costs. They may not start costly actions to cut erosion, pollution, and congestion. As a result, 
customers may not experience true eco-tourism in the resort (Cater \& Lowman, 1994).

Eco-tourism can and will be a great contributor to the education of international travelers, as well as to the growing global middle class who are traveling in their own countries, and local people who are hosting ecotourists. The opportunity for a genuine exchange of environmental values between customer and their hosts and the reawakening of the importance of traditions that value a destination's land and spirit cannot be underrated if an eco-tourism practice can truly get in touch with the hearts and minds of both - convincing them that efforts that support to conserve the environment can formulate a difference between the chances of achieving conservation and sustainable development into the future (Cater\& Lowman, 1994).

\subsection{Tourist Satisfaction}

The concept of satisfaction, as far as completeness or wholeness, is a worldwide one. Not all buyers encounter a similar fulfillment from a similar service experience (Pizam and Ellis, 1999). The feelings of satisfaction or dissatisfaction are shaped during and after the utilization of a product or service, measuring it is a post-decision, evaluative judgment resulting from a specific purchase selection and the experience of using or consuming it (Mowen \& Minor, 1998). A satisfied customer will be loyal to the company, and this loyalty is evaluated through customer retention, which ultimately is a measure for the economic sustainability of the business.

Consumer satisfaction includes three basic components (Giese \& Cote (2000): the type of response, it means that the reaction is cognitive, affective or conative, and its level of intensity, the matter on which the response is focused, which could be based on an assessment of product standards, product consumption experiences, the moment in time at which the assessment is made, which may be before selection, after selection, 
after consumption, after stretched experience, or at just about any other time.

Customer satisfaction is widely recognized as a key influence in the formation of customers' intentions to repurchase (Taylor \& Baker, 1994). Satisfied customers are also expected to tell others about their positive experiences and thus involve optimistic word of mouth advertising. Dissatisfied customers are likely to change brands and engage in negative word of mouth advertising. Tourists' satisfaction can be measured with their holiday experience, and the measurement of satisfaction provides some indication of the degree of customer loyalty (Tribe and Snaith, 1998). Thus, there is a relationship between overall satisfaction and the intention to make a repeat visit (Kozak, 2001). Environmental initiatives fall within the category of "plus" attributes because customers may see them in several different ways. Environmental attributes create a strong positive influence on overall satisfaction. But some customers may have less concern about environmental issues and give them less importance. Those customers would evaluate environmental attributes unfavorably, but the evaluations should not reduce the overall satisfaction ( Robinot \& Giannelloni, 2010).

\subsection{Behavioral Intention}

Behavioral intention denotes "instruction that people give to themselves to behave in a certain way." Repurchase intentions, word of mouth publicity, loyalty are the main aspects of behavioral intention. When the customers are satisfied, they make a positive behavioral intention towards the organization. The behavioral intentions of clients are identified in the literature as an important forecaster of the profitability of service firms (Reichheld \& Sasser, 1990). Both the costs and the revenue of firms are affected by repeat purchases, positive word-of-mouth recommendations, etc.

Tourists' behavior is divided into three phases, including pre-visitation, during visitation, and post visitation (Rayan, 2002). Wong and Kwong (2004) 
specified that repeated visitors increase word-of-mouth and such recommendations affect potential visitors. The travelers who were satisfied with the entire experience were recommending the destination to others rather than to revisit it in the future. Even though various examinations have been led to distinguish revisit-intentions and recommendations, there is no general agreement among scholars regarding the antecedents of revisit intention ( Hui, Wan, \& Ho, 2007).

Cronin, Brady, \& Hult (2000) express that perceived value might be a superior indicator of repurchase intention than either satisfaction or quality. Zabkar, Brenc, \& Dmitrovic (2010) investigated the complex connection between main constructs and behavioral intentions.

The Theory of reasoned action and theory of Planned Behavior provide green hotel practitioners with an important implication that investigating that the consumers' behavioral intentions and attitudes towards the green hotel would be the first step to predict whether consumers would choose green hotels to stay (Chen \& Tung, 2014). The current study thus measures tourists' behavior intentions towards green hotels, which are the intentions to stay in green hotels and the willingness to cooperate with green hotels' in an environmentally friendly manner.

\section{Methodology}

\subsection{Research Site}

In this research study, the researcher has done the research based on the topic, "The effect of green practices on tourist behavioral intention: A study of hoteliers in the Central Province of Sri Lanka. Among the nine provinces, the researcher selects only one province to narrow down a very broad field of research into an easily researchable topic. The researcher has selected Central Province as the research site due to the availability of eco-resorts. According to the SLTDA accommodation guide, the highest number of ecoresorts can be found in the Central Province of Sri Lanka. 


\subsection{Conceptualization}

According to the literature review, the researcher has aimed to identify the green practices of hoteliers and their effects on tourist behavioral intention. Therefore, based on past literature, the conceptual framework was developed.

Figure I: Conceptual Framework

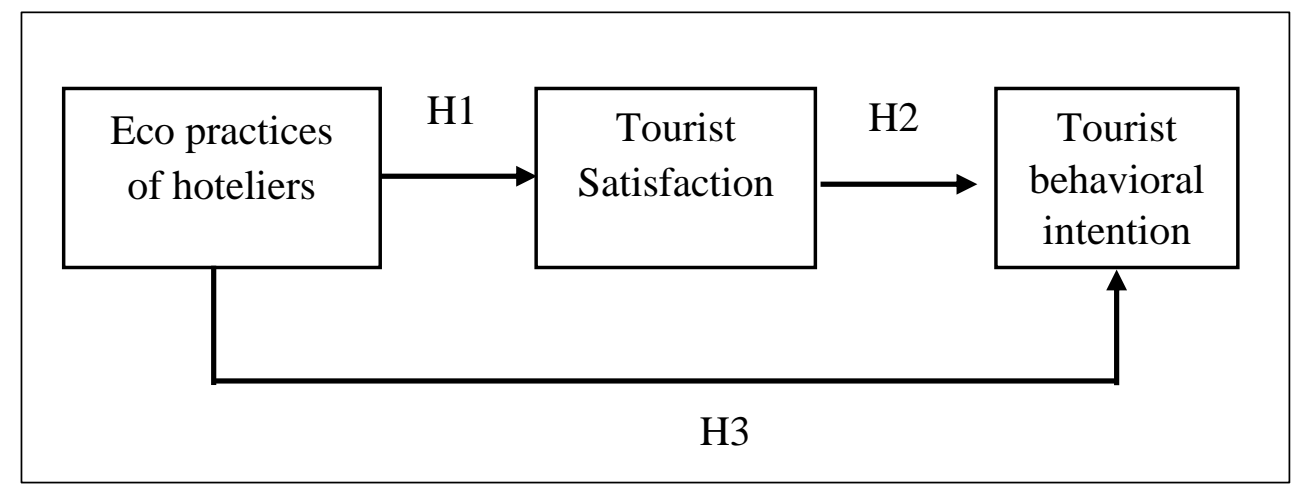

Source: Constructed by author

\section{3 Operationalization of variables}

Table 1: Operationalization of variables

\begin{tabular}{|l|l|}
\hline Variable & $\begin{array}{l}\text { Sources } \\
\text { (Variables/Dimensions) }\end{array}$ \\
\hline Independent Variable & (The international eco-tourism \\
Eco practices of hoteliers & society, 2000:2005 \& \\
- Natural Area Focus & Green globe 21 standards) \\
- Interpretation & \\
- Environmental Sustainability Practice & \\
- Conservation & \\
- Benefiting Local Communities & \\
- Cultural Respect & \\
$-\quad$ Responsible Marketing & \\
\hline
\end{tabular}




\begin{tabular}{|c|c|}
\hline $\begin{array}{l}\text { Independent Variable } \\
\text { Eco-tourists satisfaction } \\
\begin{aligned} \text { - } & \text { Meets pre-purchase expectations } \\
& \text { ( price/time/experience) } \\
- & \text { Perceived value } \\
- & \text { Customer-oriented } \\
\text { - } & \text { Wise choice }\end{aligned}\end{array}$ & $\begin{array}{l}\text { (Olorunniwo \& Hsu, 2006) } \\
\text { (Olorunniwo et al., 2006) } \\
\text { (Aydin \&Ozer, 2005) } \\
\text { (The international eco-tourism } \\
\text { society, 2000:2005 \& } \\
\text { Green globe } 21 \text { standards) }\end{array}$ \\
\hline $\begin{array}{l}\text { Dependent variable } \\
\text { Eco-tourists behavioral intention } \\
\begin{aligned}-\quad \text { Intention to revisit } \\
\text { (retention) } \\
-\quad \text { Loyalty } \\
-\quad \text { Recommending the resort to others }\end{aligned}\end{array}$ & (Clemes et al., 2009) \\
\hline
\end{tabular}

\subsection{Research Hypotheses}

The researcher has developed three hypotheses to measure the relationship between green practices of hoteliers, tourist satisfaction, and behavioral intention.

$\mathrm{H} 1$ : There is a significant relationship between eco practices of hoteliers and tourist satisfaction

$\mathrm{H} 2$ : There is a significant relationship between tourist satisfaction and tourist behavioral intention

$\mathrm{H} 3$ : There is a significant relationship between eco practices of hoteliers and tourist behavioral intention

\subsection{Research Design}

The purpose of this study was to explore the nature of understanding green practices and their effects on tourist behavioral intention. In this study, the extent of researcher interference with the study was minimal. The study was conducted in a non-contrived setting, which is a natural environment where events normally take place. The unit of analysis of the study is the individual tourist since all the data were collected from the tourists who 
stayed in the eco-resorts. The current study is a cross-sectional study, as data were gathered just once.

\subsubsection{Sources of Data}

The study consists of both primary and secondary data. Primary data are collected from tourists in Central Province. Questionnaires were given to the tourists to collect primary data to identify tourist satisfaction and revisit intention on green practices of hoteliers in Central Province. SLTDA accommodation guide November 2016 - April 2017, locally published newspaper articles, magazines, journal articles, research reports, books, and the internet are also used as secondary data sources.

\subsubsection{The population of the study}

The target population of the study was all tourists who selected eco-friendly hotels in the Central Province of Sri Lanka. Selected hoteliers are registered under the Sri Lanka Tourism and Development Authority. 15 hotels with green practices in Central Province were identified based on the accommodation guide of the Sri Lanka Tourism and Development Authority. Selected resorts are advertising green practices through their web sites. The hotels were categorized into three scales by considering the number of rooms of each hotel. It was classified to get an idea and check about the tourists' behavior based on the types or sizes of the eco-hotels. Hence the hotels were categorized as follows;

Table 2: Hotel Classification

\begin{tabular}{|l|l|l|}
\hline Scale & Number of rooms & $\begin{array}{l}\text { Number of resorts are } \\
\text { available }\end{array}$ \\
\hline Small- scale hotels & $1-50$ & 3 \\
\hline Medium-scale hotels & $50-100$ & 5 \\
\hline Large scale hotels & More than 100 & 7 \\
\hline
\end{tabular}




\subsubsection{Sampling technique and sample size}

When eco-tourists are considered as the population, the population is unknown. By using a formula with a confidence level of $95 \%$, a precision rate of $+5 \%$, and the degree of variability of $50 \%$ sample has been identified. The sample was selected using a convenience sampling strategy.

$$
\mathrm{n} 0=\frac{\mathrm{Z} 2 \mathrm{p}(1-\mathrm{p})}{\mathrm{e} 2}=\frac{1.962 * 0.5 * 0.5}{0.052}=385
$$

\subsubsection{Data Collection Methods}

The primary data required for the study were collected from tourists through a structured questionnaire. The current study used a convenience sample of 385 tourists. Tourists who accommodate in the 15 eco-hotels are asked to fill questionnaires, and the e-mails were used to communicate with past tourists to understand their satisfaction and to ask their opinions regarding various green practices of hotels. Secondary data required for the study were collected through annual statistical reports and the website of the SLTDA.

\subsubsection{Method of Data Analyzing}

Data were analyzed using SPSS version 21 data analyzing tool. In statistics, Regression Analysis is a collective name for techniques for the modeling and analysis of numerical data consisting of values of a dependent variable and one or more independent variables. The testing of the hypothesis was done using the regression analysis. 


\section{Data analysis}

\subsection{Sample profile of the study}

390 questionnaires were distributed to collect data, 358 were returned. From those, 11 questionnaires were incomplete. 134 questionnaires were rejected because the purpose of stay mentioned was not 'eco-tourism'. The researcher had to collect data only from eco-tourists because of the lack of knowledge of other tourists on green practices. Altogether 213 questionnaires were used in the analysis.

\subsection{Regression Analysis}

\subsubsection{Green Practices of Hoteliers and Tourist Satisfaction}

This relationship was measured using the following hypothesis, $\mathrm{H} 1$ : There is a significant relationship between eco practices of hoteliers and tourist satisfaction. Here the independent variable (green practices) considered were energy saving, water conservation, waste management, eco-friendly room suppliers, training and communication \& eco-friendly design. Table 3 below provides the model-fit results of the 'Enter' simple regression test using the above independent variable and tourist satisfaction as the dependent variable. Model 1 shows a significant $(p<0.05)$ $F$ value. The $R^{2}$ for this model is 0.516 , which indicates that $51.6 \%$ of the variations in tourist satisfaction are explained by the regression. 
Table 3: Model Summary- Green Practices of Hoteliers and Tourist Satisfaction

\begin{tabular}{llllllll}
\hline & & \multicolumn{9}{c}{ Change Statistics } & & Durbin- \\
Model & $\mathrm{R}$ & $\mathrm{R}$ & Adjusted & R Square & & Watson \\
& & Square & R Square & Change & F Change & Sig. F Change & \\
\hline 1 & $.718^{\mathrm{a}}$ & .516 & .514 & .516 & 224.894 & .000 & 2.258 \\
\hline
\end{tabular}

a. Predictors: (Constant), Green Practices

When conducting a regression analysis, several assumptions must be met to generalize the findings to the population (Field, 2009) The statistical analysis presented measures to suggest that these assumptions are being met in this regression model. An effective regression model should be free from multicollinearity. That implies there should be no strong relationship among the predictor variables. Many options are provided in SPSS to test multicollinearity. It was decided to use the Variation Inflation Factor (VIF) value and tolerance statistics to test multicollinearity. According to Bowerman \& O' Connell, if VIF is greater than 1 then the regression may be biased and according to Menard tolerance below 0.2 denotes a potential problem ( as cited by Field, 2009). The average VIF value and the tolerance value of this model show that collinearity is not an issue for this model.

Another assumption is the independence of the residuals. As mentioned by Field (2009), for any two observations, the residual terms should be uncorrelated. This assumption can be tested by using the Durbin- Watson test. The normal standard is that if this value is close to 2 then the assumption has almost certainly been met. The Durbin- Watson statistic for this model is 2.258 which is greater than 2 . A rule of thumb is that test statistic values in the range of 1.5 to 2.5 are relatively normal. Field (2009) suggests that values under 1 or more than 3 are a definite cause of concern. Hence the residuals of this model are independent.

Table 4 below provides statistics relating to the independent variables of the Model given in table 3. It shows that independent variables contributing to the variation in tourist satisfaction. 
Table 4: Coefficients - Green Practices of Hoteliers and Tourist Satisfaction

\begin{tabular}{|c|c|c|c|c|c|c|c|}
\hline \multirow{2}{*}{ Model 1} & \multicolumn{2}{|c|}{ Unstandardized Coefficients } & \multicolumn{3}{|l|}{ Standardized } & \multicolumn{2}{|l|}{ Collinearity } \\
\hline & B & Std. Error & Beta & & & Tolerance & VIF \\
\hline (Constant) & -6.865 & 3.089 & & -2.222 & .027 & & \\
\hline Eco Practices & .754 & .050 & .718 & 14.996 & .000 & 1.000 & 1.000 \\
\hline
\end{tabular}

a. Dependent Variable: Tourist Satisfaction

The $b$ value of this model is 0.754 , which depicts a positive relationship between the green practices of hoteliers and tourist satisfaction. The significance value of the predictor $(p<0.05)$ suggests that the predictor significantly contributes to the model.

In summary, the data supports $\mathrm{H}_{1}$. From the results of the statistical tests, it is clear that green practices of hoteliers are related to tourist satisfaction.

\subsubsection{Tourist Satisfaction and Behavioral Intention}

The relationship was tested using the following hypothesis,

$\mathrm{H} 2$ : There is a strong relationship between tourist satisfaction and tourist behavioral intention. The hypothesis was tested using regression analysis. In this tourist, satisfaction was considered a dependent variable. A significant $(p<0.05) F$ value indicates the significance of the model. It has an $R^{2}$ of 0.668 , indicating that $66.8 \%$ of the variations in behavioral intentions are explained by the regression.

Table 5: Model Summary- Tourist Satisfaction and Tourist Behavioral Intention

\begin{tabular}{lllllllll}
\hline & & & \multicolumn{5}{c}{ Change Statistics } \\
Model & R & R Square & Adjusted & R Square & $F$ & Sig. & $F$ & Durbin- \\
& & & R Square & Change & Change & Change & Watson \\
\hline 1 & $.817^{\text {a }}$ & .668 & .666 & .668 & 423.628 & .000 & 2.073
\end{tabular}

b. Dependent Variable: Tourist Behavioral Intention 
The Durbin- Watson statistic for this model is 2.037 , which is not an issue for the model.

Table 6 provides statistics relating to the independent variable of the model depicted in table 5. Tourist satisfaction appears to contribute to the variation in their behavioral intention.

Table 6: Coefficients - Tourist Satisfaction and Tourist Behavioral Intention

\begin{tabular}{|c|c|c|c|c|c|c|c|}
\hline \multirow[t]{2}{*}{ Model 1} & \multicolumn{2}{|c|}{$\begin{array}{l}\text { Unstandardized } \\
\text { Coefficients }\end{array}$} & \multirow{2}{*}{$\begin{array}{l}\text { Standardized } \\
\text { Coefficients } \\
\text { Beta }\end{array}$} & \multirow[t]{2}{*}{$\mathrm{T}$} & \multirow[t]{2}{*}{ Sig. } & \multicolumn{2}{|c|}{$\begin{array}{l}\text { Collinearity } \\
\text { Statistics }\end{array}$} \\
\hline & B & Std. Error & & & & Tolerance & VIF \\
\hline (Constant) & 31.758 & 1.375 & & 23.097 & .000 & & \\
\hline Tourist & .581 & .028 & .817 & 20.582 & .000 & 1.000 & 1.000 \\
\hline Satisfaction & & & & & & & \\
\hline
\end{tabular}

Table 6 provides a $b$ value of 0.581 , which indicates a positive relationship between tourist satisfaction and tourist behavioral intention. The significance value of the predictor $(p<0.05)$ suggests that the predictor significantly contributes to the model. In summary, the data supports $\mathrm{H}_{2}$. From the results of the statistical tests, it is clear that tourist satisfaction is related to tourist behavioral intention.

\subsubsection{Green Practices of Hoteliers and Tourist Behavioral Intention}

The relationship was measured using the following hypothesis, H3: Green practices of hoteliers have a significant effect on the behavioral intention of tourists.

Table 7 shows the model- fit results of the simple regression test using the independent variables mentioned and behavioral intention as the dependent variable. The model shows a significant value $(p<0.05)$. The 
model has an $\mathrm{R}^{2}$ of 0.543 , indicating that $54.3 \%$ of the variations in the behavioral intention are explained by the regression.

Table 7: Model Summary- Green Practices of Hoteliers and Tourist Behavioral Intention

\begin{tabular}{llllllllll}
\hline & & \multicolumn{7}{l}{ Adjusted } & \multicolumn{2}{l}{ Change Statistics } \\
Model & $\mathrm{R}$ & R Square & R Square & R Square & $F$ & Sig. & F & Durbin- \\
& & & & Change & Change & Change & Watson \\
\hline 1 & $.737^{\text {a }}$ & .543 & .541 & .543 & 251.160 & .000 & 2.048 \\
\hline
\end{tabular}

a. Predictors: (Constant), Eco Practices

b. Dependent Variable: Behavioral Intention

The Durbin - Watson statistic for this model is 2.048 , which indicates that the residuals of this model are independent.

Table 8 below provides statistics relating to the independent variable of the model in 7. Green practices of hoteliers appear to contribute to the variation in tourist behavioral intention.

Table 8: Coefficients - Green Practices of Hoteliers and Tourist Behavioral Intention

\begin{tabular}{|c|c|c|c|c|c|c|c|}
\hline \multirow[t]{2}{*}{ Model 1} & \multicolumn{2}{|c|}{$\begin{array}{l}\text { Unstandardized } \\
\text { Coefficients }\end{array}$} & \multirow{2}{*}{$\begin{array}{l}\text { Standardized } \\
\text { Coefficients } \\
\text { Beta }\end{array}$} & \multirow[t]{2}{*}{$\mathrm{t}$} & \multirow[t]{2}{*}{ Sig. } & \multicolumn{2}{|c|}{$\begin{array}{l}\text { Collinearity } \\
\text { Statistics }\end{array}$} \\
\hline & B & $\begin{array}{l}\text { Std. } \\
\text { Error }\end{array}$ & & & & Tolerance & VIF \\
\hline (Constant) & 23.764 & 2.055 & & 11.566 & .000 & & \\
\hline $\begin{array}{l}\text { Eco } \\
\text { Practices }\end{array}$ & .606 & .038 & .737 & 15.848 & .000 & 1.000 & 1.000 \\
\hline
\end{tabular}

Table 8 provides a $b$ value of 0.606 , which indicates a positive relationship between the predictor variable and green practices of hoteliers. The significance value of the predictor $(p<0.05)$ suggests that the predictor significantly contributes to the model. In summary, the data supports $\mathrm{H}_{3}$ 
concerning the green practices of hoteliers. The statistical tests depict that green practices of hoteliers are related to tourist behavioral intention.

\section{Results and Discussion}

The main focus of this study was on exploring the effect of green practices of hoteliers on tourist behavioral intention. Further, the role of tourist satisfaction in generating behavioral intention of tourists was also explored. When considering the demographic profile of the tourist who stayed in ecoresorts in Central Province researcher did a survey using 06 questions to determine the demographic profile of the tourists. The study was conducted by using 213 tourists who stayed at eco-resorts in Central Province within the concerned period. When considering gender composition, $53 \%$ of respondents represent the female category. It is not a considerable amount comparing to male visitors which represents $47 \%$. The majority of the respondents were between 36-45 years. As a tendency, most of the middle age (36-45 years) tourists $28 \%$ desire to stay at ecofriendly resorts. Most of the respondents were graduates or diploma holders. It represents more than $45 \%$ of the respondents. It is a significant number. $12 \%$ of respondents were completed post-graduate degrees. Understandably, eco-tourists' education level is very high. Even consider the income level of the tourists, USD 10,000-29,999 income level represented a higher portion out of all respondents. It can be said that a higher amount of respondents stayed in eco-resorts represented the average income category. It was found that most tourists were from Europe, represented $44 \%$ out of all respondents, while $29 \%$ of tourists represented Asia. Hence it can be identified that Europeans are more concerned about the green concept than other tourists.

The first objective of this study was to identify the relationship between green practices of hoteliers and tourist behavioral intention. This study considered six dimensions (green practices), which significantly contribute to the behavioral intention of tourists namely energy saving, water conservation, waste management, eco-friendly room supplies, 
environmental education and awareness, environmental concern. It was found that $54.3 \%$ of the variation in behavioral intention was explained by the green practices of hoteliers. This finding contradicts the findings of (Manaktola \& Jauhari, 2007). In their study, they have identified a significant relationship between tourist behaviors towards green practices in the hotel industry.

The second objective of this study was to explore the effect of green practices on tourist satisfaction. The hypothesis was green practices of hoteliers have a positive relationship with tourist satisfaction. The results of the statistical test indicated that $66.8 \%$ of the variation in satisfaction is explained by the green practices of hoteliers. A considerable variation in satisfaction is explained by the green practices of hoteliers. The study was done by Arachchi (2015) focused on behavioral intention and green practices where the researcher has considered seven eco components that have found that the satisfaction of tourists has a significant effect on green practices of hoteliers in Sri Lanka.

\subsection{Managerial Implications}

When it comes to the implications of the concept, it is important to point out the importance of practicing these eco concepts in a country like Sri Lanka and the demand for it in the global context. The eco-tourism market is growing at around $20 \%$ per year, significantly higher than the annual rate of $4 \%$ for tourism as a whole, and these tourists are more willing to pay extra for eco-tourism than for standard tourism packages (Magee, 2005). She further stated that eco-resorts are just one building type where sustainable concepts, in particular, make sense. The largest market study ever undertaken was for Canada in 1995. It determined that the natural setting is the most critical factor in determining a quality product. According to the study of Magee, tourists showed an increased desire to find experiences in environments that were well managed, and recreational activities and multiple activities were desired. When promoting the concept of eco-tourism, managers have to face a major difficulty. That is the poor 
understanding, and different practices of eco-tourism and eco-resort practices in Sri Lanka compared to the international level.

Attaching the "eco-tourism" label to poorly planned programs provides the local population with little besides social tension and environmental degradation while leaving the genuine eco-tourist dissatisfied and cheated. Most of the big resorts are just concrete jungles, and still, they claim them as eco-resorts. According to the study, the issue of failing to practice the eco-tourism concept in eco-resorts happened due to the following reasons.

- Sri Lanka's eco-tourism business is not being guided by international principles.

A "National Policy Plan on Eco-Tourism" is yet to be formulated by the tourism authorities in Sri Lanka

There are no true eco-resort operators, those who adhere to the eco-resort principles.

- $\quad$ There are no sufficient qualified people to handle eco-tourists.

\section{Conclusion}

In the Sri Lankan context, most of the areas consist of the number of the resort, which promotes themselves as eco-resorts. There are various areas in the hotels where these concepts can be incorporated conveniently and affect tourist satisfaction and behavioral intention. The current study was conducted with the main focus of identifying the effect of green practices of hoteliers on tourist satisfaction and behavioral intention. Green practices of hoteliers can affect the favorable behavioral intention of tourists.

According to the findings, most of the eco hoteliers in Central Province misused the eco concept, acted as greenwashers, and affected the behavioral intention of tourists. Hence, there is a possibility of losing the eco-tourism market from the Sri Lankan tourism industry; it will badly affect all parties who engaged with the tourism industry. Finally, the researcher concluded the green practices of hoteliers affect the behavioral intention of 
tourists and the absence of the real eco concept of the Sri Lankan ecoresort badly affects the behavioral intention of tourists.

\subsection{Directions for Future Research}

A replication of this study is recommended to broaden the scope of the research as the present study was limited to the Central Province of Sri Lanka. It was pointed out that demographic variables have not been identified as moderating variables in this study. Due to that further research is needed demographic factors as a moderator variable. Further, the researcher has not considered the mediator effect of the tourists' satisfaction on the relationship between eco practices of hoteliers and behavioral intention. Hence future researchers can concern about that area.

Obtaining responses from tourists is also an area that can be improved in future studies. In conducting the present study, a questionnaire was distributed to some tourists outside the hotel. Since the study is mainly focusing on green practices of hoteliers, it would be better if the responses are obtained from tourists in the hotel itself.

\section{References}

Arachchi , R. S, S,W., Yajid , M. S., \& Khatibi . A. (2015).A Comparison of EcoTourism Practices of Sri Lankan Hoteliers with Reference to the International Standards. Tourism, Leisure and Global Change, 155-171.

Bottrill, C.G. and Pearce,D.G.(1995) Eco-tourism :Towards a key elements approach to operationalising the concept, Journal of Sustainable Tourism.

Campbell, L. M. (1999).Eco Tourism in Rural Developing Countries. Annals of Tourism Research. 534-553.

Cary, J., Bhaskaran, S., \& Polonsky M. (2004).Green Marketing and EM. Rural Industries Research and Development Corporation.

Cater, E., \& Lowman, G. (1994).Ecotourism: A Sustainable Option.John Wiley and Sons, Chichester, UK 
Chen, M., \& Tung, P. (2014).Developing an extended Theory of Planned Behavior model to predict consumers' intention to visit green hotels.International Journal of Hospitality Management, 21-230.

Clemes. M.D. et. al. (2009).An empirical study of behavioral intentions in the Taiwan hotel industry. Journal of Innovative Marketing, Vol.5 No 3.

Cronin, J.J., Brady, M.K. and Hult, G.T. (2000) Assessing the Effects of Quality, Value and Customer Satisfaction on Consumer Behavioral Intentions in Service Environments. Journal of Retailing

Field, A. (2009) Discovering Statistics Using SPSS. 3rd Edition, Sage Publications Ltd., London

Font, X. (2002). Environmental certification and hospitality: progress, Process and Prospects. Journal of Tourism management, Vol.23, pp.197-205.

Garrod, B. \& Fyall, A. (1998).Beyond the rhetoric of sustainable tourism.Journal of Tourism management, Vol.19, No 3, pp.199-212.

Giese, J.L. and Cote, J.A. (2000). Defining Consumer Satisfaction. Academy of Marketing Science Review.

Greenwashing index help keep advertising honest. (n.d.). Retrieved from Greenwashing index: http://greenwashingindex.com/

Hui, K. T., Wan, D., \& Ho, A. (2007).Tourists' satisfaction, recommendation and revisiting Singapore.Tourism Management, 965-975.

Isaacs, J.C. (2000).The Limited Potential of Ecotourism to Contribute to Wildlife Conservation.Wildlife Society Bulletin,Vol. 28, No 1, 61-69. Published by: Allen Press.

Jackson , L. A. (2010).Toward a framework for the components of green lodging. Journal of Retail \& Leisure Property ,211-230.

Jamaluddin, M. (2004).Sustainable architecture in tropical hotel developments: Approaches to the design of Malaysian coastal resorts.

Kozak, M. (2001).Repeaters' behaviour at two distinct destinations.Annals of Tourism Research, Vol. 28 No. 3, pp. 784-807

Lee, J. S., Hsu, L.T., Han, H., \& Kim, Y. (2010).Understanding how consumers view green hotels: how a hotel's greenimage can influence behavioural intentions.Journal of Sustainable Tourism, 901-914. 
Lee, W., \& Moscardo, G. (2005).Understanding the impact of eco-tourism resort experiences on tourists'environmental attitudes and behavioral intentions. Journal of Sustainable Tourism, 546-565.

Manaktola, K., \& Jauhari, V. (2007).Exploring consumer attitude and behaviour towards green practices in the lodging industryin Indial.nternational Journal of Contemporay Hospitality Management, pp.364-377.

Melissen, F., \& Roevens, J. (2007).Greening the Hotel Industry: Imposible, Inconvenient, or Shrewd?.Breda University of Applied Sciences International Hotel Management School Breda.

Mowen, J., \& Minor, M. (1998).Consumer behavior. Prentice hall.

Nair, V., \& Ananthrajah, S. (2012).Green makeover of our hotel.

Olorunniwo, F., \& Hsu, M.K. (2006).A typology analysis of service quality, customer satisfaction and behavioral intentions in mass Services. Managing Service Quality Vol. 16 No. 2, pp. 106-123

Olorunniwo, F., Hsu, M.K., \& Udo,G.J. (2006).Service quality, Customer satisfaction, and behavioral intentions in the service factory. Journal of Services Marketing, Vol.20 No 1,pp.59-72

Orams, M. B. (1995).Towards a more desirable form of eco tourism.Tourism Management, 3-8.

Pizam, A., \& Ellis, T. (1999).Customer satisfaction and its measurement.International Journal of Contemporary Hospitality, pp.326339.

Reichheld, F.F., \& Sasser, W.E. (1990).Zero defections: quality comes to services. Harvard Business Review, pp. 105-11.

Ryan, R. M., \& Deci, E. L. (2002). An overview of Self-determination Theory: An organismic-dialectical perspective. In E. L. Deci \& R. M. Ryan (Eds.), Handbook of self-determination research. 3-33. Rochester, NY: The University of Rochester Press.

Robinot, E., \& Giannelloni, L. (2010).Do hotels' "green" attributes contribute to customer satisfaction?. Journal of Services Marketing, pp.157-169.

Ross, S., \& Wall, G. (1999).Ecotourism:towards congruence between theory and practice.Tourism Management, pp.123-132. 
Taylor, S.A. and Baker, T.L. (1994) An Assessment of the Relationship between Service Quality and Customer Satisfaction in the Formation of Customers' Purchase Intentions. Journal of Retailing, 70, 163-178.

The International Eco Tourism Society. (1993).Eco tourism guidelines for nature tour operators. The International Eco Tourism Society, Burlington, VT, USA

Trauer, B. (1998).Green tourism in the hotel and resort sector: International and New Zealand perspectives.Australian Parks and Leisure 1, No 2, 5-9.

Tribe, J., \& Snaith, T. (1998).From SERVQUAL to HOLSAT: holiday satisfaction in Varadero, Cuba.Tourism Management, Vol. 19 No. 1, pp. 25-34.

World Tourism Organization . (n.d). Retrieved from Why tourism?: http://www2.unwto.org/content/why-tourism

Zabkar, V., Brenc, M. M., \& Dmitrovic, T. (2010). Modelling perceived quality, visitor satisfaction and behavioural intentions at the destination level. Tourism management 